\title{
RISK RELATED TO THE IMPLEMENTATION \\ OF INNOVATIVE PROCESSES \\ BY ENTERPRISES IN THE SME SECTOR. \\ ANALYSIS OF THE RELATIONSHIP BETWEEN \\ THE QUANTITY OF IMPLEMENTED INNOVATIONS \\ AND THE FINANCIAL RATE OF RETURN ACHIEVED
}

\author{
TOMASZ NOREK \\ University of Szczecin, Faculty of Management and Economics of Services, POLAND \\ e-mail: norek@wzieu.pl
}

RECEIVED
ACCEPTED
JEL
CLASSIFICATION

KEYWORDS

ABSTRACT
10 December 2018

28 December 2018

030,031

innovation and innovativeness, risk in innovation, SME sector in Poland

In modern global economy, the ability to create and implement innovations is a key factor in building the enterprise's competitiveness and increasing its value. Despite indisputable benefits resulting from the implementation of innovation, running innovative activity also generates significant risks and uncertainties associated primarily with the need to incur expenditures on the development and launching of innovation, as well as the inability to clearly determine whether the new product will gain positive market acceptance. The author put forward the following thesis: $(\mathrm{H} 1)$ : there is a positive relationship between innovation efficiency (the number of implemented/absorbed innovations) and the efficiency of innovative activities of enterprises in the SME sector, thus increasing experience in the implementation of innovation processes reduces the risks associated with implementing new solutions and increasing the efficiency of implemented innovation processes. The study used the exploratory-descriptive method, which consists in statistical aggregation of the obtained results in selected analytical cross-sections. Empirical data was obtained using an online questionnaire and study involved 361 companies registered throughout the country, actively operating during the study period.

\section{Introduction as justification for choosing a research problem}

In modern global economy, the ability to create and implement innovations is a key factor in building the enterprise's competitiveness and increasing its value. This applies equally to all enterprises operating on the market, both large international corporations and enterprises belonging to the SME sector. Innovations are very often associated with the implementation of advanced, breakthrough solutions on a global scale, usually associated 
with technologies and production. Meanwhile, the innovative activity is diversified - from product and technological innovations to new solutions in the field of organization and marketing, or finally new social solutions. The scale of changes obtained as a result of innovation implementations is also very different - there are breakthrough innovations, i.e. new global solutions concerning entire sectors and branches of the economy but there are also small incremental solutions affecting only the enterprise itself. Due to such a wide impact of innovation, despite the obvious limitations resulting from the specificity of enterprises in the SME sector (e.g.: limited financial and personnel resources allowing for the implementation of innovative activities), these are the small and medium-sized enterprises that are increasingly inclined to conduct innovative activities.

Despite indisputable benefits resulting from the implementation of innovation, running innovative activity also generates significant risks and uncertainties associated primarily with the need to incur expenditures on the development and launching of innovation, as well as the inability to clearly determine whether the new product will gain positive market acceptance. In this situation, it is significant to determine whether conducting innovative activity by enterprises in the SME is profitable.

There is a broad discussion in literature on the essence and significance of risk in innovative activities (Piśniak, 2017; Skowron, 2013). Attempts are also made to identify and manage risk factors (Vargas-Hernandez, 2011, pp. 47-53; Keizer, Halman, 2007, pp. 32-35). Literature, however, does not mention studies describing the negative effects of risk implementation or the possibility of reducing the risk of running innovative activity. Attempts to assess the risk related to running innovative activity in the context of financial results achieved was made by T. Nawrocki (2016), who used comparative research to determine that innovative activity of enterprises involves a greater risk of negative changes in the size of financial ratios than in the case of enterprises with more traditional business profiles (Keizer, 2009, pp. 512-513).

The author of this publication attempted to answer the following question: does experience in conducting innovative activity, expressed by the number of successful implementations of innovations on the market reduce the risk of conducting innovative activities? The author believed that direct effects from the implementation of new products or services to the market was a sign of reducing the risk, which was determined by financial results obtained or acceptance of new products on the market. The author put forward the following thesis: $(\mathrm{H} 1)$ : there is a positive relationship between innovation efficiency (the number of implemented / absorbed innovations) and the efficiency of innovative activities of enterprises in the SME sector, thus increasing experience in the implementation of innovation processes reduces the risks associated with implementing new solutions and increasing the efficiency of implemented innovation processes.

\section{Risk in innovative processes. Literature review and conceptual framework}

Innovations through product, process and organizational transformations make it possible to introduce new, improved products to the market: both goods and services. In this sense, innovations are considered to be the main driving force of socio-economic development increasing competitiveness, as well as the source of entrepreneurship and creativity. Nowadays, innovations should be the basis for achieving the company's intended goals, because of the dynamics of changes in the economy. Technical and technological progress, as well as adaptation to changes in customer expectations forces the introduction of new solutions and products, which allows enterprises to strengthen their competitive advantage. Competition, both between companies and sectors, regions and countries, is considered to be the driving force of innovation. 
It is widely accepted that innovation is a new solution that contributes to the improvement of the organization's functioning. The concept of innovation was introduced by Joseph A. Schumpeter (1960, p. 104), describing it as:

1. Introduction of new products into production or improvement of existing ones.

2. Introduction of new production methods or improvement of existing ones.

3. Applying new methods of production organization.

4. The use of new raw materials or semi-finished products.

5. Opening a new market.

Innovation can be considered from two perspectives, innovation as a process and as a result. The first of them most often concerns changes in processes, products, organization, and social life. The second one is referred to as changes in the sphere of production, as a result of which new products are created (Madyda, Dudzik-Lewicka, 2014, p. 134; Damanpour, 1987, p. 677). Innovation is also understood as "generating, accepting and implementing new ideas, processes, products or services" (Kanter, 1983, p. 20).

Nowadays, due to the name adopted by OECD experts and widespread in EU regulations, the definition of innovation in the Oslo textbook is commonly used. According to its methodology, innovation means implementing a new or significantly improved product or process, at least for the implementing unit and related to any of its areas of functioning. In the case of an enterprise, it may concern the product offered, a new marketing method, its creation process, a new organizational method in business practice, workplace organization or relations with the environment (Os/o Manual..., 2008, p. 48). The foregoing definition of innovation was accepted by the author as commonly used in this article.

Numerous scientific studies clearly point to a positive translation of innovative activity (innovativeness) of enterprises into their competitiveness, improvement of financial results or building in a positive image of a modern and dynamic enterprise. Despite the indicated positive aspects of innovative activity, in practice this activity is characterized by a high degree of risk resulting from the need to bear significant expenditures and uncertainty regarding the work effect (Świtalski, 2005, pp. 23-26; Pudło, 2012, pp. 83-87).

Risk considerations have been introduced into economic sciences and are undertaken in the area of various fields of science, including economics, behavioral sciences, legal sciences, psychology or statistics and probabilities. The wide spectrum of states that the concept of risk refers to makes it difficult to formulate a precise and clear definition. Risk considerations were introduced to economic sciences in the 18th century by English researcher R. Cantillon, who noticed the impact of risk on the level of income and business uncertainty (Cantillon, 1938). The first attempt to define the concept of risk was made in 1901 by A.H. Willett, stating that "risk is something objective, related to subjective uncertainty" (Willett, 1901, p. 504). Another definition was proposed in 1921 by F. Knight, who published in his doctoral dissertation entitled "Risk, Uncertainty and Profit" the concept of measurable and unmeasurable uncertainty, where the first was called a risk and the other an uncertainty in the strict sense (Knight, 1964). The definition, commonly referred to and accepted by economists as classical, was proposed by J.M. Keynes in the publication "A Treatise on Probability", recognizing that the risk relates to events that are known to be probable, and in addition can be quantified (Keynes, 1921, pp. 315-319).

Nowadays, in the domain of economic sciences and management sciences, the risk is usually defined as the danger of incurring a loss, the possibility of an unfavorable event or failure to achieve the intended purpose (often following the decision). The risk can also be identified with a situation in which not all variables are estimated or cannot be estimated on the basis of probability calculations - managers have the possibility to assess risk 
(probability of occurrence of specific threats), and also its control, to some extent (Aven, Renn, 2009, p. 7; Janasz 2009, pp. 90-92).

The transfer, contemporary and widely accepted understanding of risk to the level of business practice, primarily exposes the possibility of incurring losses as a result of undertaking a specific action, which is extremely important from the point of view of management of decision-making processes, for example regarding investment activities or activities aimed at generating innovative solutions.

Krzysztof Janasz presented a precise analysis of selected theoretical aspects of risk and uncertainty in business operations. (Janasz, 2009), and M. Bochenek conducted a broad and exhaustive discussion on semantics related to the notion of risk and uncertainty in economic sciences (Bochenek, 2012).

As previously noted, the characteristic feature of innovative processes is the high degree of risk (JonekKowalska, 2011, pp. 5-11). The specificity of managing innovative activity requires constant decisions that are rarely made in conditions of total certainty. In the context of innovative activity of enterprises, risk is of particular importance, as innovative undertakings, by their very nature to change reality, provoke risk (Jarus, 2011). It can be stated that the level of risk in an innovative undertaking is directly proportional to the scale and scope of innovation - the greater the scale of innovation, the greater the likelihood of failure.

The risk of innovation concerns primarily the decision to undertake the innovation process. This decision causes a number of subsequent threats related to individual stages of the innovation process.

The high degree of risk of innovation activity is caused by the need to incurr significant financial and material outlays as well as involving the resources in the form of work. An extremely important factor from the point of view of managed risk is also the distribution of expenditures in time - a large part of research and development expenditures, design, prototype construction, testing, marketing research is incurred before the product is launched, i.e. before the period in which revenues from the sale of a new solution will be generated. Furthermore, in many cases, innovation processes do not reach the commercialization phase and new solutions are not introduced to the market, thus they do not generate revenue (profit) for an enterprise. high percentage of failures in implementing innovations is caused by uncertainty about the effects of work on new solutions and the risk of the market's lack of acceptance for the new solution. These risks may of course be organic, e.g. marketing research or market tests of proposed innovations.

Enterprises from the SME sector very rarely (almost never) have separate research and development departments, providing appropriate organization of individual stages of the innovation process. The development of new ideas is usually dealt with by individuals (or small teams) whose experience and viewer grows with successive ventures. In the context of the main research objective of this article, it should be noted that the risk related to the implementation of innovations can be significantly reduced due to the accumulation of knowledge and experience in the implementation of innovation processes and cooperation with specialized research units, other enterprises or knowledge transfer centers

Nevertheless, this means that the implemented innovation, which ended with effective commercialization, has been accepted by the market and has been put into practice or on the market, must ensure reimbursement of not only the costs of its production, but also the outlays incurred for other unsuccessful implementations (Szwajca, 2013, pp. 25-27; Keizeir, 2009).

In subject literature, various classifications of the risk sources of innovative activity may be encountered. Assuming the risk area criterion for A. Pomykalski (2001, p. 167), the following may be distinguished: 
1. Micro level - the risk resulting from the company's activity, which consists of: organizational, marketing, production, financial risk, personnel management or profitability of the investment.

2. Intermediate level - market risk, which includes: economic situation in a given industry, level of competition, barriers to entry into the market, ways of acquiring new and maintaining existing clients.

3. Macro level - the risk that results from macroeconomic and global conditions: economic situation in a given country, global economy, volatility of exchange rates, tax regulations, customs regulations, etc., interest rate volatility, political conditions, global development, technology flow, etc.

4. The risk of operating on foreign markets, resulting from operating in a different environment: economic, legal, political, etc.

The above criteria refer to the risk of conducting innovative activity, it can be stated that in the case of implementing new solutions, enterprises are exposed to risk at each of these levels, although the most important risks for the SME sector are those belonging to the micro level and the intermediate level. This is due to the range of activity of enterprises in the SME sector (most often it is regional operations, less frequently activities on a national scale and rarely on an international scale) and the scale of implemented innovations determined by the degree of novelty of the proposed solution (most often they are innovations on the scale of the enterprise, less frequently market or industry, and very rare breakthrough innovations in the world). K. Janasz (2009, p. 91) proposed a different breakdown (aspect) of risk sources in economic activity:

- economic risk,

- financial risk,

- liquidity risk,

- currency risk,

- country risk,

- transfer risk,

- interest rate risk,

- risk of an event.

Analyzing the proposed sources of risk in the context of the practice of implementing innovative processes, it can be concluded that enterprises from the SME sector are primarily exposed to economic and financial risk (and consequently to the liquidity risk). It results from the previously mentioned fact that the implementation of virtually all innovative processes requires specific expenditure (financial and material) and the involvement of the company's resources (work). Enterprises from the SME sector during the implementation of innovative processes are exposed to currency risk, transfer risk or country risk to a lesser extent, which results from previously reported characteristics of enterprises operating in the SME sector.

Considering the sources of risk affecting undertaking of innovative activities, it should also be noted that there is a risk related to discontinuation of innovative activity - in conditions of high competition in most modern markets, enterprises that discontinue innovative activity risk the loss of competitiveness and consequently exclusion from the market.

\section{Research metod, sample and limitations}

The main purpose of this publication is to try to answer the question: if in the case of enterprises from the SME sector, experience in the implementation of innovative processes reduces the risk of failure associated with 
the implementation of new solutions. The author adopted the obtained direct implementation effects, i.e. percent share of profit from the sale of innovation of in total profit and the rate of return on innovation calculated for individual implementations (ROI2 ratio) as a factor confirming the reduction of risk. Thus, the author assumed that experience and knowledge acquired during subsequent implementations of innovative processes reduce the risk of failure and thus increase the direct effect.

The author puts forward the hypothesis: (H1): there is a positive relationship between innovation efficiency (the number of implemented/absorbed innovations) and the efficiency of innovative activities of enterprises in the SME sector, thus increasing experience in the implementation of innovation processes reduces the risks associated with implementing new solutions and increasing the efficiency of implemented innovation processes.

The study used the exploratory-descriptive method, which consists in statistical aggregation of the obtained results in selected analytical cross-sections. Empirical data was obtained using an online questionnaire containing 64 questions - an online survey carried out using the Audit Platform of the Faculty of Management and Economics of Services at the University of Szczecin.

In the first part of the survey, entrepreneurs filled out the company's certificate containing, among others:

- contact details,

- year of establishment,

- employment (allowing for qualification: micro, small, medium),

- a leading type of activity according to PKD (allowing for qualification: industrial/production activity, service activity),

- origin of capital (national/international),

- main area of activity,

- scope of activity.

In the second part of the survey, entrepreneurs introduced detailed data on innovative activity in the analysed period, i.e. among others on:

- number of successful and unsuccessful implementations of innovations,

- innovation trends (absorption/diffusion),

- type of innovation,

- total expenditure on innovative activity,

- total net revenues from innovative activities,

- market assessment of acceptance of implemented innovations,

- period of implementation of innovative activity,

- sources of innovation financing (use of EU funds or lack thereof).

Additional information obtained in the study were: expected rate of return from innovative activity or competences in the assessment of own effectiveness of innovative activity. The survey was conducted in the period 01.2018-09.2018.

The survey questionnaire was designed in such a way (selection of descriptive features and data measures) to use the OLAP method (OnLine Analytical Processing) in the data analysis, allowing multidimensional correlation of data. Based on the collected data, the author calculated and compared selected performance indicators of innovative processes (e.g. ROI2) for all surveyed enterprises - taking into account the assumption that the accumulated stream of profits/outlays for each of the surveyed enterprises was implemented (documented) for at 
least one year. The obtained results were subjected to statistical descriptive analysis. According to the principle of logical induction, the obtained results were generalized and based on them the author verified the research hypothesis.

The study involved 361 companies registered throughout the country, actively operating during the study period. Assuming the universally recognized number of employees as a criterion of the size of enterprises, the number of microenterprises was 205 (57\% of the sample), the number of small enterprises was 112 (31\% of the sample) and the number of medium enterprises was 44 (12\% of the sample). The structure of the research sample due to the size of employment is presented in Table 1.

Enterprises were selected for the size of the enterprise purposefully (according to the commonly accepted division taking into account the employment in the survey year, i.e. enterprises: micro, small, medium) and the leading type of activity consistent with the Polish Classification of Activities (Polish Classification of Activities, i.e.: industrial/manufacturing enterprises and service enterprises). Taking the leading type of activity as the criterion, the sample structure was as follows: manufacturing / industrial enterprises $=139$ (39\% of the trial), service enterprises $=222(61 \%$ of the trial).

Table 1. Research sample structure

\begin{tabular}{lrccc}
\hline \multirow{2}{*}{ Type of company } & \multicolumn{3}{c}{ Size of company } & \multirow{2}{*}{ Total } \\
\cline { 2 - 4 } & micro & small & average & \\
\hline Production & 70 & 54 & 15 & 139 \\
Services & 135 & 58 & 29 & 222 \\
\hline Total & 205 & 112 & 44 & 361 \\
\hline
\end{tabular}

Source: own elaboration based on research data.

The author is fully aware that the applied research sample is not representative, but the targeted selection of enterprises for research was to ensure the implementation of the survey on a sample similar to the statistical picture of SME sector in Poland (according to the sector image published by the Central Statistical Office).

\section{Results and discussion}

The key feature from the point of view of the research objective was the number of successful and unsuccessful innovations declared by respondents. As an innovative activity, the authors accept the implementation by the company (diffusion or absorption) of any innovation that meets the criteria of the Oslo Handbook (2005). Successful implementations of innovations showed those implementations for which entrepreneurs could show profit. Table 2 presents the number of innovation implementations for the trial under consideration, taking into account the size of the enterprise and the leading type of business.

The surveyed enterprises have implemented a total of 652 products or services that they considered to be innovations - by adopting the criterion of the impact of innovations described at the company level, at the local level, or at the national or international level described in the Oslo textbook. Micro enterprises implemented 362 innovations (56\% of all implemented innovations), small enterprises implemented 192 innovations (29\% of all implemented innovations), while medium enterprises implemented 98 innovations (15\% of all implemented innovations). The median of implementations for the tested sample amounted to 2 implementations regardless of the 
size group. The maximum number of innovation implementations demonstrated due to the size of the surveyed enterprises was as follows: 6 regardless of the size of the examined enterprise.

Table 2. Number of successful and unsuccessful implementations of innovations

\begin{tabular}{lcc}
\hline Type of company & $\begin{array}{c}\text { Number of successful innovation } \\
\text { implementations }\end{array}$ & $\begin{array}{c}\text { Number of failed innovation } \\
\text { implementations }\end{array}$ \\
\hline Micro & 362 & 106 \\
Production & 122 & 39 \\
Services & 240 & 67 \\
\hline Small & 192 & 54 \\
Production & 86 & 24 \\
Services & 106 & 30 \\
\hline Average & 98 & 22 \\
Production & 33 & 3 \\
Services & 65 & 19 \\
\hline Total & 652 & 182 \\
\hline
\end{tabular}

Source: own elaboration based on research data.

The surveyed enterprises, which indicated the production activity as a leading type of activity, implemented 241 innovations (37\% of all implemented innovations), while service enterprises implemented 411 innovations (63\% of all implemented innovations). The maximum number of innovation implementations demonstrated due to the leading type of activity of the surveyed enterprises was as follows: manufacturing enterprises -6 implementations, service enterprises -6 implementations. Taking into account the leading type of business, the average and median of implementations, as before, amounted to 2 implementations for each group.

In order to verify the hypothesis $(\mathrm{H} 1)$, the author conducted two analytical sections:

1. A summary of the average return on innovation calculated using the ROI2 ratio in relation to the number of implemented innovations. The list was made taking into account the division of enterprises due to the size of the surveyed enterprises, as well as the type of activity.

2. A statement of percent of the average profit obtained from the sale of innovation in relation to the profit of the examined enterprise in total with reference to the number of implemented innovations. The list was made taking into account the division of enterprises due to the size of the surveyed enterprises, as well as the type of activity.

Analysis of the obtained results leads to the conclusion that in this case it is difficult to clearly show the relationship between the number of implemented innovations and the obtained rate of return from innovation.

For micro enterprises declaring 1 implementation (113 surveyed enterprises), the average rate of return amounted to $9.35 \%$, while for enterprises declaring 6 implementations (the maximum declared number of implementations, 2 surveyed enterprises) the rate was $18.00 \%$. In this case, the difference is $8.65 \%$, and the relative increase in the average rate of return was $92.61 \%$.

For small enterprises declaring 1 implementation ( 60 surveyed enterprises), the average rate of return amounted to $11.15 \%$, while for enterprises declaring 6 implementations (maximum declared number of implementations, 1 examined enterprise) the rate amounted to $26.00 \%$. In this case, the difference was $14.85 \%$, and the relative increase in the average rate of return was $133.18 \%$ 
For medium enterprises declaring 1 implementation (16 examined enterprises), the average rate of return was $14.88 \%$, while for enterprises declaring 6 implementations (maximum declared number of implementations, 2 examined enterprises), this rate amounted to $29.50 \%$. In this case, the difference is $14.63 \%$, while the relative increase in the average rate of return amounted to $98.32 \%$.

For the whole sample of enterprises declaring 1 implementation (189 surveyed enterprises), the average rate of return amounted to $10.39 \%$, while for enterprises declaring 6 implementations (the maximum declared number of implementations, 5 surveyed enterprises) the rate was $24.2 \%$. In this case the difference is $13.81 \%$, while the relative increase in the average rate of return was $133.00 \%$.

Table 3. The number of successful implementations of innovations in comparison with the obtained rate of return on innovation

\begin{tabular}{|c|c|c|c|c|c|c|c|}
\hline \multirow{2}{*}{ Type of company } & \multicolumn{6}{|c|}{ Number of innovation implementations } & \multirow{2}{*}{ Total average } \\
\hline & 1 & 2 & 3 & 4 & 5 & 6 & \\
\hline Micro & 9.35 & 10.64 & 11.14 & 10.50 & 14.50 & 18.00 & 10.12 \\
\hline Production & 9.15 & 11.05 & 9.17 & 18.75 & 27.00 & 17.00 & 10.59 \\
\hline Services & 9.45 & 10.41 & 11.93 & 6.38 & 10.33 & 19.00 & 9.87 \\
\hline Small & 11.15 & 11.27 & 9.11 & 9.33 & & 26.00 & 10.94 \\
\hline Production & 11.91 & 12.54 & 7.13 & 6.00 & & & 11.24 \\
\hline Services & 10.29 & 10.29 & 10.70 & 11.00 & & 26.00 & 10.66 \\
\hline Average & 14.88 & 17.14 & 16.75 & 36.50 & 24.00 & 29.50 & 18.00 \\
\hline Production & 19.20 & 25.00 & 21.00 & & & 42.00 & 23.13 \\
\hline Services & 12.91 & 12.78 & 12.50 & 36.50 & 24.00 & 17.00 & 15.34 \\
\hline Average & 10.39 & 11.77 & 11.32 & 13.35 & 17.67 & 24.20 & 11.33 \\
\hline
\end{tabular}

Source: own elaboration based on research data.

Correlation between the number of implemented innovations and the obtained effects in the form of the average rate of return is particularly evident in the medium-sized enterprises surveyed, the smallest correlation was demonstrated for micro-enterprises. In the case of the type of business, a greater correlation between the number of innovation implementations and the achieved effects is visible for manufacturing enterprises. The cumulative results of the analysis are presented in Table 3 and Figure 1.

For micro enterprises declaring 1 implementation, the average percent share of the profit from the sale of innovations in the total profit was $8.91 \%$, while for enterprises declaring 6 implementations, the rate was $19.00 \%$. In this case, the difference is $10.09 \%$, and the relative increase in the average rate of return was $113.21 \%$.

For small enterprises declaring 1 implementation, the average percent share of profit from sales of innovations in total profit was $10.50 \%$, while for enterprises declaring 6 implementations, the rate was $18.00 \%$. In this case, the difference was $7.50 \%$, and the relative increase in the average rate of return was $71.43 \%$.

For medium enterprises declaring 1 implementation, the average percent share of the profit from the sale of innovations in the total profit was $12.94 \%$, while for enterprises declaring 6 implementations, the rate was $24.50 \%$. In this case, the difference is $11.56 \%$, and the relative increase in the average rate of return was $89.37 \%$. 


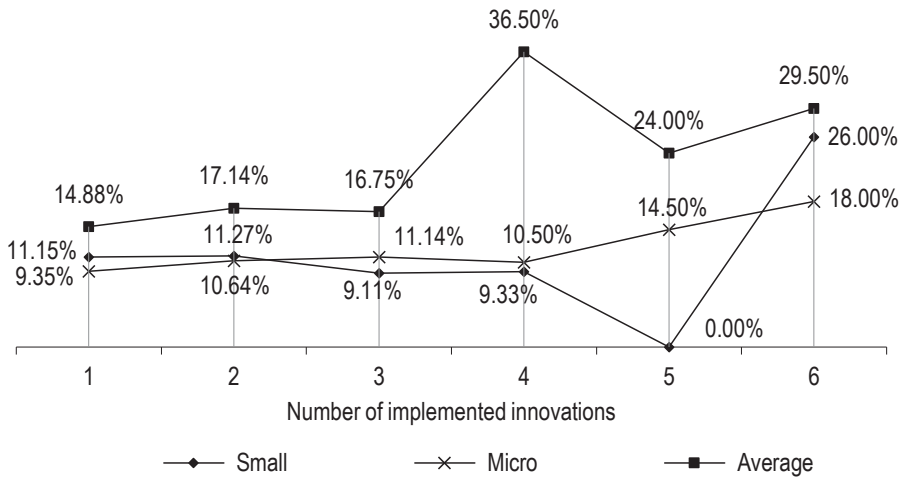

Figure 1. The number of successful implementations of innovations in comparison with the obtained rate of return on innovation

Source: own elaboration based on research data.

Correlation between the number of implemented innovations and the obtained results in the form of a share of profit from the sale of innovations in total profit is particularly visible in the medium-sized enterprises surveyed, the smallest correlation was demonstrated for micro-enterprises.

Table 4. Number of innovation implementations in the statement with the share of percent profit from the sale of innovations in total profit

\begin{tabular}{|c|c|c|c|c|c|c|c|}
\hline \multirow{2}{*}{ Type of company } & \multicolumn{6}{|c|}{ Number of innovation implementations } & \multirow{2}{*}{ Total average } \\
\hline & 1 & 2 & 3 & 4 & 5 & 6 & \\
\hline Micro & 8.91 & 10.70 & 8.40 & 14.50 & 14.75 & 19.00 & 9.86 \\
\hline Production & 8.74 & 14.42 & 8.90 & 4.50 & 8.00 & 17.00 & 10.16 \\
\hline Services & 9.00 & 8.62 & 8.20 & 19.50 & 17.00 & 21.00 & 9.70 \\
\hline Small & 10.50 & 8.39 & 11.17 & 18.00 & & 18.00 & 10.31 \\
\hline Production & 12.34 & 7.88 & 12.38 & 33.00 & & & 11.66 \\
\hline Services & 8.39 & 8.79 & 10.20 & 10.50 & & 18.00 & 9.06 \\
\hline Average & 12.94 & 8.50 & 14.50 & 12.00 & 19.00 & 24.50 & 12.57 \\
\hline Production & 20.60 & 12.00 & 13.75 & & & 26.00 & 16.27 \\
\hline Services & 9.45 & 6.56 & 15.25 & 12.00 & 19.00 & 23.00 & 10.66 \\
\hline Average & 9.76 & 9.67 & 10.50 & 14.82 & 16.17 & 21.00 & 10.33 \\
\hline
\end{tabular}

Source: own elaboration based on research data.

For all examined enterprises declaring 1 implementation, the average percent share of the profit from sales of innovations in the total profit was $9.76 \%$, while for enterprises declaring 6 implementations, the rate was $21.00 \%$. In this case, the difference is $11.24 \%$, and the relative increase in the average rate of return was $115.24 \%$.

In the case of the type of business, a greater correlation between the number of innovation implementations and the achieved effects is visible for manufacturing enterprises. The cumulative results of the analysis are presented in Table 4. 


\section{Conclusions}

The author's goal was to show the connection between experience in the implementation of innovative projects and the risk related to the effectiveness of implementing new solutions - in relation to Polish enterprises in the SME sector. The author assumes that, with the increase of experience and the knowledge created on its basis, enterprises reduce the risk related to the implementation of innovative processes and are able to implement more effective innovations on the market. In response to such a defined research problem, the author formulated a research hypothesis ( $\mathrm{H} 1$ ): there is a positive relationship between innovation efficiency (the number of implemented/ absorbed innovations) and the efficiency of innovative activities of enterprises in the SME sector, thus increasing experience in the implementation of innovation processes reduces the risks associated with implementing new solutions and increasing the efficiency of implemented innovation processes.

The obtained results of the statement of the number of implemented innovations with the obtained effects in the form of the average rate of return and the \% share of profit from the sale of innovations in total profit, allow for a positive verification of the $\mathrm{H} 1$ hypothesis. Nevertheless, it should be emphasized that this conclusion may be debatable due to the type of distribution of declared implementations - 1 implementation was declared by 189 surveyed enterprises, and the greater number of innovation implementations declared a significantly smaller number of enterprises: 4 implementations - 17 enterprises, 5 implementations - 6 enterprises, respectively 6 deployments -5 enterprises. This evidently left-sided distribution of the phenomenon may provoke discussions as to the comparability of results and full validity of inference. A methodical solution to the doubts would be to base the conclusion on a large research sample (preferably representative), but in the case of SME sector research, obtaining such tests in the case of individual tests is particularly difficult.

At this point it should be recalled that in accordance with the adopted research method, the obtained results constitute a statistical description of the studied phenomenon and compare the results obtained in accordance with the features of the surveyed enterprises. The purpose of the author's work was not to determine causal relationships between the established values of the effects of the innovative activity of the surveyed enterprises, and their specific characteristics resulting from the business activity or the characteristics of managing the innovation processes.

It seems that research on causal relationships should constitute the next stage of research on the risks associated with the implementation of innovative processes in the SME sector. The effect of such research could be to determine the specific characteristics of enterprises (both internally and externally), which reduce the risk of implementation of innovation processes and the identification of those features that are key determinants of innovation risk implemented by enterprises in the SME sector. Creating a description of such features will enable effective risk modelling in the area of innovative activity and thus increase the efficiency of these processes.

Another direction of research may be a comparative analysis of risk factors in the area of innovative activity identified for Polish enterprises of the SME sector with enterprises from other countries - especially countries that are leaders in innovation (e.g. the most innovative countries of the European Union). A comparative analysis in this area would enable the creation of a model of good practices in the area of risk management in innovative projects and thus the removal of barriers to conducting effective innovation activities by Polish enterprises in the SME sector. 


\section{References}

Aven, T., Renn, O. (2009). On risk defined as an event where the outcome is uncertain. Journal of Risk Research, 12 (1), 1-11.

Bochenek, M. (2012). Ryzyko i niepewność w naukach ekonomicznych - rozważania semantyczne. Ekonomia 4 (21), 46-63.

Cantillon, R. (1938). Ogólne rozważania nad naturalnymi prawami handlu. Warszawa: Szkoła Główna Handlowa w Warszawie Skład Główny „Biblioteka Polska”. Retrieved from: https://upload.wikimedia.org/wikipedia/commons/0/01/Richard_Cantillon_-_ Og\%C3\%B3Ine_rozwa\%C5\%BCania_nad_naturalnymi_prawami_handlu_\%281938\%29.pdf.

Damanpour, F. (1987). The adoption of technological, administrative and ancillary innovations: Impact of organizational factors. Journal of Management, 13, 675-688.

Janasz, K. (2009). Ryzyko i niepewność w gospodarce - wybrane aspekty teoretyczne. Zeszyty Naukowe Uniwersytetu Szczecińskiego. Studia i Prace Wydziału Nauk Ekonomicznych i Zarządzania, 14, 87-98.

Jarus, T. (2011). Nie ma ryzyka, nie ma innowacji. Retrieved from: www.pi.gov.pl/parp/chapter_86196.asp?soid=A805BEAED1F24A8 890FCF66E4AE57D13.

Jonek-Kowalska, I. (2011). Źródła ryzyka w procesie wprowadzania innowacji technologicznych. Zarządzanie i Edukacja, 80, 5-25.

Kanter, R.M. (1983). The change masters. New York: Simon \& Schuster.

Keizeir, J., Halman, J. (2007). Diagnosing risk in radical innovation projects. Research Technology Management, 50 (5), 30-36.

Keizer, J. (2009). Risk in major innovation projects, a multiple case study within a world's leading company in the fast moving consumer goods. International Journal Technology Management, 48 (4), 499-517.

Keynes, J.M. (1921). A Treatise on Probability. London: Macmillan and Co.

Knight, F.H. (1964). Risk, Uncertainty and Profit, Reprints of Economic Classics. New York: Augustus M. Kelley.

Madyda, A., Dudzik-Lewicka, I. (2014). Innowacyjność a rozwój małych i średnich przedsiębiorstw. Zeszyty Naukowe Wyższej Szkoły Humanitas. Zarządzanie, 1, 133-140.

Nawrocki, T. (2016). Ryzyko działalności innowacyjnej przedsiębiorstw w kontekście ich wyników finansowych. Nauki o Zarządzaniu 1 (26), 112-124.

Oslo Manual. Proposed Guidelines for Collecting and Interpreting Technological Innovation (2008). European Commission. OECD.

Piśniak, M. (2017). Ryzyko jako determinanta innowacyjności przedsiębiorstwa. Zeszyty Naukowe Politechniki Częstochowskiej, Zarządzanie, 25 (t. 2), 105-115.

Pomykalski, A. (2001). Zarządzanie innowacjami. Warszawa: Wydawnictwo Naukowe PWN.

Pudło, P. (2012). Charakterystyka barier rozwoju działalności innowacyjnej w ujęciu kapitału intelektualnego - wyniki badań. Nierówności Społeczne a Wzrost Gospodarczy, 25, 81-90.

Schumpeter, A. (1960). Teoria rozwoju gospodarczego. Warszawa: PWN.

Skowron, P. (2013). Ryzyko w działalności innowacyjnej przedsiębiorstwa. Prace Naukowe Wałbrzyskiej Wyższej Szkoły Zarządzania i Przedsiębiorczości, 25 (5), 241-255.

Świtalski, W. (2005). Innowacje i konkurencyjność. Warszawa: Wydawnictwo Uniwersytetu Warszawskiego.

Szwajca, D. (2013). Efektywność działań marketingowych w cyklu życia produktu - podstawy metodyki pomiaru. Zeszyty Naukowe. Organizacja i Zarządzanie/Politechnika Śląska, 66, 23-32.

Vargas-Hernandez, J. (2011). Modeling risk and innovation management. Journal of Competitiveness Studies, 19 (3/4), 45-57.

Willett, A.W. (1901) The Economic Theory of Risk and Insurance. New York: The Columbia University Press. Retrieved from: https:// www.casact.org/pubs/forum/91wforum/91wf469.pdf.

Cite this article aS: Norek, T. (2018). Risk related to the implementation of innovative processes by enterprises in the SME sector. Analysis of the relationship between the quantity of implemented innovations and the financial rate of return achieved. European Journal of Service Management, 4 (28/2), 299-310. DOI: 10.18276/ejsm.2018.28/2-36. 